\author{
Гордана Вулевић \\ Одељене за психологију \\ Филозофски факултет, Универзитет у Београду \\ e-mail:gvulevic@f.bg.ac.rs
}

\title{
СВЕТИ ЈОВАН ЛЕСТВИЧНИК НАРАТИВНА ФУНКЦИЈА ТАМНИЦЕ
}

Апстракт: Лествичникова Тамница је прича о једној необичној монашкој обитељи. Тамнииу, вели он, настағују, монаси покајници, кривцуи без кривице. Свесни греха а лишени кривице, они, житељи ове чудне обитељи, стојећи под ведрим небом непрекидно прекоревају себе. Слике патње монаха, готово на ивици душевне поремећености, смењују слике измучених тела. Описи су упечатљиви, одишу сировошћу афективитета. Нескривено је наглашен конкретан телесан аспект патье. Чулност описа на тренутке готово да код рецииијента ствара утисак опште пренадражености и зазора. Ова епизода, која се помиње једино у четвртој и петој поуци, стилски се разликује од осталог текста. Разликује се и по свом садржају. У остатку Лествице, Лествичник је углавном доследно аналитичан. У Тамници нам се Лествичник, између осталог, представља као врстан приповедач. Таквим приповедањем (можда и фикционим) на крајње ефектан начин појачава дејства свог аналитичког дискурса. Теме попут сећања на смрт и онтолошки дубоко неизвесног статуса човека чине важну, очигледно изоштрену потку иеле Лествице. Жалосна и узнемирујућа слика начина живота и умирања житеља Тамнице представљала је суштинску опозицију мистичкој радости преображеног ероса. Дакле, нечег ито је у самом Лествичниковом тексту, макар на први поглед, тек имплицитно назначено.

Кључне речи: Свети Јован Лествичник, Лествица, Тамница, покајање, организачија наратива

Опис живота у сасвим нарочитој монашкој обитељи запамћеној под несвакидашњим називом Тамница ( Лествице, насловљеној „О блаженој и незаборавној послушности“.

Посреди је, вели Лествичник, монашко обитавалиште лишено сваке, па и оне најелементарније удобности живљења. Између осталог, житељи овог манастира су лишени ватре, уља, вина. Исхрана им је крајње оскудна. Хране се искључиво хлебом и некаквим поврћем. Монасима је овде, поједностављено речено, ускраћена могућност да напусте манастир. У њему живе као да су у тамници. Зашто? Разлог томе је чињеница да су они, мучени житељи ове обитељи, ступивши у монашки чин запали у страсти.

Лествичников опис је овде, у четвртој поуци, кратак и, на први поглед, узгредан. Детељнија разрада ће уследити у следећој (петој) поуци, оној посвећеној покајағу. ${ }^{1}$

1 У свом необјављеном тексту о Лествици, у који сам имала увид, Петар Јевремовић примећује да су схолијасти причу о Тамници, упркос њеној неспорној снази, држали ван сфере свог интересовања. 
Лествичник нам казује своју причу на крајње занимљив начин. Обраћа нам се као сведок. Као неко ко је тамо доиста био, ко се лично уверио у све оно о чему нам говори. У Тамници је провео тридесет дана. Како сам каже, толико је издржао. Више није могао. При том, наравно, не смемо заборавити, изворно се Лествичник овде (као, уосталом, у целом тексту Лествице) обраћа монасима. Они су његова примарна публика. Одмах пада у очи стил његовог обраћања.

Своју причу о Тамници он организује по моделу усменог говора. Обраћајући се, он приповеда. Најпре позива реципијенте своје беседе (монахе) да прићу, да и они сами чују и виде, оно што је својевремено њему (зарад спасења) Бог приказао.

Монах је, вели Лествичник, анђелски чин. Његов чин, у поретку вредности оновремене културе, нужно (наравно, у својој идеалној форми) подразумева анђелски живот. То није мала ствар, и то Лествичник добро зна. То знају и његови, условно речено, слушаоци. Или читаоци. У сваком случају, исти они монаси којима се обраћа текстом своје Лествице.

У том кључу ваља нам разумети следеће Лествичникове речи. „Монах је човек који се држи само Божјих заповести и речи, у свако време и на сваком месту, у сваком послу. Монах, то је непрестано приморавање природе и неуморно бдење над својим чулима. Монах, то је посвећено тело, то су очишћена уста и просвећен ум. Монах, то је преболна душа, стално обузета сећањем на смрт, било да бди или да спава“.2 Монах може да падне, али мора да устане. Да се покаје. Да сам себи изрекне казну.

Покајање је за Лествичника обнова крштења, завет дат Богу да ће се човек преобразити. Покајање за Лествичника има изузетну сотериолошку вредност. Стога, он каже: „Устаните и стојте, ви који сте оборени гресима. Обратите пажњу, браћо моја, на ову моју поуку: нагните ухо своје, ви који хоћете да се поново измирите са Богом истинским обраћањем“. 3 Високи идеалитет монашког живљења, нимало случајно, овде стоји у оштрој опозицији спрам питорескне страве коју, убрзо ћемо видети, собом доноси опис Тамнице. Реторичко умеће приповедача овде је потпуно у служби намере да се, што је могуће више, сликом и речју подучи читалац.

Лествичник се, дакле, обраћа читаоцима као да су они његови слушаоци. Захтева пажюу и активну партиципацију. Чини то чврсто верујући у трансформациони потенцијал речи. Отуд, већ сад можемо закључити, његова приповест о Тамници никако не може бити сведена на ниво пуког преношења информација. Другим речима, он (своје читаоце, тј. слушаоце) примарно не жели о нечему (о Тамници) напросто да информише: да их, својом причом упути у неке фактички важне чињенице. Уз сву реторику историчности његовог наратива, он, пре свега, жели да у самим реципијентима свог текста, управо речима које изговара, индукује иманентан процес трансформације.

Од монаха који живе у Тамници очекује се покајање. Покајање се очекује и од свих других монаха. Покајање је смисао монашког живота. Штавише, можемо додати, покајање је смисао хришћанског живота уопште. За Лествичника Тамница је слика; жива слика, осликана (попут древног средњевековног игроказа) јаким тоновима и пренаглашеним контрастима.

Пред нама је призор. Њега чини мноштво слика. Те су слике зналачки опосредоване речима. Лествичникове слике су упечатљиве, гротескне. Преплићу се страшно и смешно. Ружно и узвишено.

Схолије на Лествичников текст објављене су заједно са самим текстом Лествище, у 88. тому Мињове Грчке патрологије. Ипак, до данас нису у целини објављене схолије Илије Критског, вероватно најобимнијег Лествичниковог коментатора. О томе уп. Богдановић 2008.

2 Свети Јован Лествичник 2008, 20.

3 Исто, 53. 
Већ смо видели, Лествичникова Тамница је прича о једној необичној монашкој обитељи. Сам Лествичник је, нема сумње, свестан њене необичности. Штавише, на њој и инсистира.

Тамницу, вели он, настањују, монаси покајници, кривии без кривице. Свесни греха а лишени кривице, житељи ове чудне обитељи, стојећи под ведрим небом, непрекидно прекоревају себе; неки гледају у небо, вапећи за помоћ, други упиру поглед у земљу, сматрајући да су недостојни да и да погледају у небо. Мучени грижом савести, неки ударају челом о тло, неки се ударају у прса. Наричу над својом душом. Неки, замишљени, седе на земљи и као лавови ричу из дубине срца, гребући ноктима тло под собом.

На ову причу тешко је остати равнодушан. Слике патње монаха, људи готово на ивици душевне поремећености, смењују слике измучених тела. Описи су упечатљиви, одишу сировошћу афективитета. Нескривено је наглашен конкретан, телесни аспект патње. Многим су монасима, каже Лествичник, колена усахла од метанија, очи упале у лобању, трепавице отпале од проливања суза, прса болна од удараца и умрљана избљуваном крви. Чулност описа на тренутке готово код реципијента ствара утисак опште пренадражености и зазора.

Причајући своју причу, Лествичник не узмиче. Задржава се на детаљима. Инсистира на оном у њима што је за реципијенте потенцијално одбојно чак персекутивно. Могли су се, каже он, видети и монаси са усмрделим и загнојеним ранама, измршавелих тела, исплажених, запаљених језика, као у паса. У Тамници се одећа се не пере и не крпи. Тамница је место у коме је све мрачно, све смрдљиво, све запуштено.

Призор Лествичникове Тамнице дословно преплављује сва чула. Задире у сому. Иритира фантазију. У игри су, осим, наравно, високих идеала оновремене монашке културе, најдубљи слојеви оног хтонског у човеку. Нимало случајно, налазимо се у зони међусобног (верујем потенцијално плодног) преплитања искуства аскетске древности, овде упечатљиво оличене у делу св. Јована Лествичника, и савремене психоанализе. Када то кажем, поред Фројда, овде имам у виду Мелани Клајн и Жака Лакана. Уз све неспорне разлике које постоје између ова два виђења теорије и праксе бављења човеком, његовом нормалношћу и патологијом, заједничким можемо сматрати њихов посвећени интерес за оно што је у експресији човековог бића сликовно, по себи иконичко; психоанализа би рекла фантазматско, тј. имагинарно.

Слике репрезентују све оно што је (Фројд би рекао) у човеку нескућено, потенцијално болесно и аверзивно. ${ }^{4}$ Ружно. Ван сваке сумње, са овим би се, на себи својствен начин, сложио и Лествичник.

Између осталог, овде је посреди специфична естетика. Слободно можемо рећи естетика аскетизма, тачније, естетика аскетског искуства. Посредством слика распаднутог тела, вели Бичков, писци византијске агиографије су настојали да истакну моралну чистоту аскета, њихову тежњу да се уподобе Божанском идеалу. ${ }^{5}$ У њиховим текстовима су, између осталог, поједини антиестески феномени парадоксално естетизовани. На нивоу реторике овде бива назначена, за аскетизам хришћана тако битна,

4 Уп. Freud 1919.

5 УП. Бичков 2012. 
могућност преображења. Колико год само зло сезало дубоко у људско биће, какве год биле страшне размере с њим повезаног распадања и пропадања, слабости и немоћи, могуће је спасење. Грехом девастирана тварност смртника налази своју есхатолошку ентелехију у идеалитету нове твари. Зато постаје могуће оно о чему нам сам Лествичник говори: да се гнојаво тело подвижника сматра лепим; штавише, лепшим од било ког племенитог метала. 6

Унутрашња лепота о којој је овде реч је, Бичков то са ваљаним разлогом наглашава, заправо је есхатолошки залог нове твари. Улога симбола је, у оваквом поретку ствари, да посредује између актуалитета болне палости бића и есхатолошки предзначене пунине, тј. лепоте. Самим тим, мукама изобличено (условно речено ружно) тело стиче статус симбола унутрашње лепоте. ${ }^{7}$

Макаријевске списе, упоредимо ли их са Лествичниковим, карактерише, макар на први поглед, другачије акцентована естетика. ${ }^{8}$ У извесном смислу, можемо рећи да овде видимо два релативно различита, свакако особена, теолошка (мистичка, аскетска) сензибилитета, легитимно присутна у оквиру исте традиције.

Ефекат Макаријевих метафора (слика) почива на контрастима. ${ }^{9}$ Причајући нам своју причу, нама непознати аутор Макаријевских списа вазда инсистира на опозицији светлост - тама. Карактеристично макаријевска (мистичка) идеја светлости подразумева сjај, блистағе. Истовремено, тама је овде много више од пуког оптичког феномена. Тежиште је на етичком, заправо мистичком виђењу човека. Ништа ново нећу рећи, Макаријевски списи обилују таквим метафорама. Слици сјаја душе човека праведника оштро је супротстављена слика таме душе човека грешника. И не само то. Сама слика душе коју је Дух себи припремио за своје обитавалиште у Макријевским списима бива високо естетизована.

Таква је душа сва светлост, сва је око. Њено биће је мистички прочишћено гледање Лепоте. Гледајући, душа собом и у себи (другима) рефлектује саму узвишену божанску Лепоту. У таквој души, у души праведника, макар у идеалном случају, нема нигде ниједног дела који не би био испуњен духовним очима, способним за мистичко гледање Божанске светлости. Она бива осветљена неописивом лепотом славе светлости лица Христовог - преобразивши се, сва постаје лице, сва бива око. Као таква, она је нетремице загледана у лепоту Бога.

У истом кључу аутор Макаријевских списа размишља и о греху. Последица греха је тама, нечистота, трулеж. Очигледно, ни по чему битном он се не разликује од Лествичника. Но, за разлику од Лествичника, он својом причом не залази у (готово

6 Бичков каже: „Естетизација ових, рекло би се крајње неестеских појава, неће нам деловати више тако апсурдно уколико се сетимо да су је византијски агиографи неговали у култури глобалног симболизма и антиноминизма, када су се ствари по својој природи у свему супротстављене, могле бити симболи и знаци, када су се сличност и истоветност сагледавале кроз принципијелну несличност и неподударност, када је крајња униженост била знак божанствене узвишености. У овој култури су се и гнојне ране доживлљавале као симболи духовне чврстине и неописивог савршенства (традиција која починње још од аутора Књиге о Јову) и због тога су деловале лепо“. Уп. Бичков 2012, 157.

7 Исто, стр. 156-157.

8 Другу збирку Макаријевих беседа ћу цитирати према издању Библиотеке ОЧЕВ ДОМ при Верском доборотворном старатељству Архиепископије београдско-карловачке. У даљем тексту ћу ово издање означавати римским бројем II. Број беседе из наведене збирке ћу означавати арапским бројевима.

9 Више о перформативним ефектима метафора (слика) у Макаријевским списима уп. Вулевић 2017. 
клиничку) аналитику особености феномена таме. Његове су метафоре много општије. Слике које користи нису тако узнемиријујће као Лествичникове.

Када нечастиви кнез, дакле царство таме, пороби човекову душу, ни један њен део не остаје слободан. Тама се тада шири (попут инфекције) и све више гута светлост, урушавајући тако само биће изворно боголике душе. Позната је макаријсвска метафора о тамном покривалу, тј. о порфири таме. ${ }^{10}$

За њега, писца Макаријевских списа, душа огреховљеног човека не припада телу светлости, већ телу таме. ${ }^{11}$ Када је човек у власти ђавола, његова душа постаје трулежна и губи сјај. Као што месо без соли трули и шири задах, тако се и људска душа, незасољена Светим Духом, испуњава злосмрадијем нечистих помисли. ${ }^{12}$ За разлику од Лествичника, текст Макаријевских омилија не иде даље, не залази у детаље. Причом коју нам прича, он, напросто, застаје на порфири таме. Више га занимају светлост, сјај и блистање. Док, као што смо видели, у Лествичниковој Тамници у први план, избија , иконографија пропадања, која ту, управо, има статус симболичке апотеозе саме макаријвске порфире таме.

И Лествичник и Макарије теже да поуче, да излече, да трансформишу субјекта посредством речи и поведу га на пут спасења. На први поглед, њихове се приче битно разликују. Док је Макарије сав у светлосним метафорама и мистичком усхићењу. Лествичниковим текстовима провејавају опори тонови и персекутивне слике. Макаријевска есхатологија је сасвим експлицитна, а Лествичникова је много више имплицитно присутна.

Циљ им је исти. И један и други својим причама желе подстаћи друге на врлину; заправо, на спасење. Слике су, бар у извесном смислу, другачије. Макарије евоцира слике трулежне душе, и, као што рекох, доследно инсистира на мистичкој светлости преображења. Лествичник у први план доводи слике трулежних, тела. За разлику од Макарија, Лествичник је много више терапеут. Макарије је много више надахнути мистик. У Лествици је однос између душе и тела дијалектички. Макаријевски списи су по свом сензибилитету ближи духу древне сиријске традиције. Његове слике су конкретне. Телесне и истовремено поетске. Лествичник је, за разлику од њега, много више аналитичар. И још нешто: много је мање семитског залеђа у подтексу Лествичниковог дискурса.

За Лествичника, представе трулежности тела настају као елемент аскетског наратива о процесу подвига и покајања. Свака стопа Лествичниковог (за многе одвећ тешког, мрачног, чак персекутивног) наратива, битно подразумева тврду веру у есхатолошку потенцијалност тог истог (посрнулог) тела.

Слике мучења и патње зато никако не треба разумети као самореферентне. Напротив, оне снажно упућују на мистичку тајну васкрсења. За Лествичника, као уосталом и за Макарија, динамика спасења не укључује само душу, већ и тело. Попут Христових мука на крсту, тела подвижника, сликовито дата у наративу о Тамнищи, слуте спасење.

$$
* * *
$$

Духовни отац је лекар. Тачније, он је терапеут у изворном значењу те речи. Грех је болест. Огреховљеност је болесно стање човековог бића, како духа тако и тела. Тражећи лек, монах се обраћа духовном оцу, показује му своје ране.

10 II, 2.

11 II 1.

12 II 1. 
Грех се лечи покајањем. Покајање је лек за огреховљену душу. Много је грехова. Нису сви исти. Много је и лекова; у овом случају, путева ка покајању. Према дубини болести, према степену (грехом условљене) некрозе бића, лекар (у овом случају духовни отац) преписује лек. Што је болест тежа, лек мора бити јачи. Том логиком се, поједностављено речено, руководио Јован Лествичник.

Тамница је метафора лечења. Она је, симболички говорећи, тополошка одредница самог тог процеса. Терапијски простор није обичан простор. Лествичник то добро зна. Слици болести кореспондира слика простора у којем се та болест може лечити. Условно речено, обичне болести се лече мање или више конвенционалним поступцима. Није свако лечење радикално. Радикалност терапијског захвата изискује озбиљна, поодмакла болест. Управо о таквој болести, болести духа и тела, говори Лествичник.

Тамница је прљаво, смрадно и тамно место. Лествичник је, на себи својствен начин, смешта с оне стране принципа задовољства. То је место терапијске конкретизације најстрашнијих могућих персекутивних и деструктивних фантазија. У питању је место бизарно и сулудо које, упркос својој страшној појавности, наговештава могућност исцељења. Већ поменуте нове твари.

У извесном смислу, то је чини болницом. У њој се, сведочи нам Лествичник, лечи људска грехом посрнула природа.

Када се душа лиши пређашње смелости пред Богом и са Богом, она се предаје мукама и тежи да саму себе уништи подвигом. Радикалност поступка кореспондира радикалности човековог посрнућа. С тим је у вези, наравно, и сам топос Тамнице, њена наглашена измештеност у односу на (условно речено) основну монашку обитељ. ${ }^{13}$

$$
* * *
$$

Намеће се питање да ли је данас, после толико времена, уопште могуће идентификовати неки историјски реалан локалитет који би одговарао Лествичниковој Тамници. Сва је прилика, ваља и то напоменути, још увек смо далеко од дефинитивног одговора на ово питање.

$\mathrm{y}$ тексту Лествице постоје индиције да је Лествичник путовао. Конкретно, боравио је у Доњем Египту, обилазио је тамношње пустињаке. Из Поуке пастиру, вели Димитрије Богдановић, могуће је закључити да је ту постојала бројна монашка обитељ. Њом је руководио неки велики, тј. славни игуман. Том игуману је била потчињена и лавра у коју је, по потреби, слао монахе ради подвига безмолвија. Ипак, сва је прилика, додаје Богдановић, да ту лавру треба разликовати од Тамнице. ${ }^{14}$

Постоји мишљење да је Тамница у ствари манастир Метанија, смештен на периферији Александрије, који је помињао још Јероним. Али, осим по строгости унутрашњег уређења, сличности по имену и топографске подударности, нема поузданих доказа да је Тамница канопска Метанија. Без основа је, сматра Богдановић, и Филаретова

13 Тамница је, каже Лествичник, од главног манастира просторно удаљена. Измештена. По свом устројству и систему вредности, она се не да ситуирати не само у град (то јест свет), већ ни у (уобичајено схваћену) пустиґу, то јест манастир. Сам топос Тамнице као и слике монашког живота израз су Лествичникове представе оваплоћењ $а$ аскетског идеала. Идеала са којим ни он сам, као што каже, није могао у потпуности да се самери: „А ја сам, гледајући и слушајући то све међу њима, умало да не паднем у очајање, познајући своју равнодушност и поредећи ту равнодушност са њиховим страдањем“. Уп. Свети Јована Лествичник 2008, 57.

14 Богдановић 2008. 
теза да је у питању чувени манастир у Тавени. Поменути се манастир налазио у Горњем Египту, док је Лествичник, ако је веровати причи, путовао по Доњем Египту. ${ }^{15}$

На основу самих Лествичниковог списа није могуће одредити (макар приближно тачан) географски локалитет Тамнице. Овде Тамница фигурира као, пре свега, један њен део; као епизода. Тачније, као прича.

За Тамницу (као причу) од пресудног значаја није ни њен историјски фактиuзтет, ни географски локалитет. Лествичник нам се ту открива много више као приповедач него као фактограф. Он својом причом, првенствено, жели да поучи. Причајући, он се обраћа публици, својим монасима.

Лествичник је свестан перформативног дејства своје беседе. Свестан је ефеката својих фантастичних, гротескних, потенцијално персекутивних слика подвига оних који су, како каже, у стању да победе чак и самога Бога. Некима ће се, каже Лествичник, подвизи о којима он приповеда чинити невероватни. Други ће изгубити наду, мислићи да им је такав подвиг недостижан. Трећи ће пасти у очајање. На оне храбре приповест делује подстицајно. Када чује за такве подвиге, храбар човек бива рањен у срце, те устаје и одлази с пламеном ревности у души. Слабијима Лествичникова прича омогућава да се самере, да упознају своју немоћ, те да прекоревајући саме себе стекну смиреноумље. Они чак могу поћи путем храбрих, али је неизвесно да ли ће их стићи. А лењ човек „нека се и не дотиче тога што је овде изнето, да не би пао у очајање и упропастио и оно што чини; тада би се испунила на њему еванђелска изрека: „Од онога који нема ревности и оно што му се чини да има - узеће се од юега (Мт. 25, 29).“ 16

Лествичник познаје људску природу. Зна да нису сви монаси једнако способни да издрже тегобе подвижничког живота. Он је само за оне који су му дорасли. Лествичникове фантастичне, гротескне, потенцијално застрашујуће слике имају функцију да наведу монаха да преиспита сопствене капацитете. Оне слабе ће одвратити. Оне који се Бога боје неће застрашити. У Поуции пастиру Лествичник вели да „никакве страшне речи не могу изазвати страх тамо где се љубав божанска коснула срца. И где се појави страх од пакла, тамо се свакојака мука трпи. Где се примети нада на царство небеско, тамо је и презир према свему земаљском.“"17

Никако не треба превидети да се цела ова прича одвија у контексту специфично осликаних оквира монашког максимализма. ${ }^{18}$

На крају желим да додам још нешто. Није немогуће да је овде, заправо, посреди фикција: монашки адаптирана приповест о фантастичном путоваьу. Релевантан је наративни топос, место које заузима Тамница у организацији Лествице. Ова епизода, (која се у наредним поукама више не помиње) стилски се разликује од осталог текста. Разликује се и по свом садржају. У остатку Лествице, Лествичник је углавном доследно аналитичан. У Тамници нам се, између осталог, представља као врстан приповедач.

\section{5 Исто.}

16 Свети Јован Лествичник 2008, 59.

17 Исто, 188.

18 Не без дивљења за житеље Тамнице, Лествичник каже:“ Где се код њих могао приметити смех? Где празнословље? Где гнев? (Они нису знали да гнев уопште постоји у људима, јер је плач уништио у њима свако осећање гнева). Где оговарање? Где бестидан језик? Где неговање тела? Где траг славољубља? Где рачунање на раскош? Где помисао на вино? Где наслађивање грла? Брига о свему томе у садашњем животу из њих је потпуно ишчезла“. Уп. Исто, 55. 
Својим приповедањем (можда и фикционим), он веома ефектно појачава дејство свог аналитичког дискурса. Теме попут сећања на смрт и онтолошки дубоко неизвесног статуса човека представљају важну, очигледно изоштрену потку целокупне Лествице. Жалосна и узнемирујућа слика живота и умирања оних у Тамници представљала је суштинску опозицију мистичкој радости преображеног ероса, дакле, нечег што је у Лествичниковом тексту, макар на први поглед, тек имплицитно назначено.

Велика мука живљења је потенцијално искушење сваког човека. То се односи и на монахе и на мирјане. Мистичка радост је плод подвига ретких. Ретки ће, исто тако, бити у стању да прате текст Лествище у целини, а поготово причу о Тамници.

\section{Литература}

Бичков, Виктор (2о12): Кратка историја Византијске естетике. Београд: Службени гласник.

Богдановић, Димитрије (2008): Јован Лествичник у Византијској и старој Српској књижвности. Бања Лука: Романов.

Vulević, Gordana (2017): Transformatin of the subject by the words in the writings of the St. Macarius the Great. Bogoslovlje, p. 85-98.

Freud, Sigmund (1919): S., Uncanny. SE, vol. XVII, London: The Hogarth Press.

Свети Јован Лествичник (2012): Лествица. Бања Лука: Романов.

Свети Макарије Велики (2012): Духовне беседе. Београд: Библиотека ОЧЕВ ДОМ при Верском доборотворном старатељству Архиепископије београдско-карловачке. 


\section{Gordana Vulević}

\section{JOHN CLIMACUS: \\ THE NARRATIVE FUNCTION OF DUNGEON}

John Climacus's Dungeon is the story of an unusual monastic family. The Dungeon, he says, is inhabited by monks repentant, guilty without guilt. Aware of sin and devoid of guilt, they, the inhabitants of this strange family, standing under the clear sky, constantly rebuke themselves. Images of the monk's suffering, almost on the verge of mental disorder, are replaced by images of tortured bodies. The descriptions are strong, they exude a rawness of affectivity. The specific bodily aspect of suffering is openly emphasized. The sensuality of the description at times almost gives the recipient the impression of general irritability and gaps. This episode, which is mentioned only in the fourth and fifth lessons, is stylistically different from the rest of the text. It also differs in its content. In the rest of its Ladder, John Climacus is mostly consistently analytical. In the case of the Dungeon, John Climacus presents itself to us, among other things, as an excellent narrator. With this mentioned (maybe even fictional) narration, he, in an extremely effective way, amplifies the effects of his analytical discourse. Topics such as the memory of death and the ontologically deeply uncertain status of man represent an important, obviously sharpened, weft of the entire Ladder. The sad and disturbing image of the way of life and death of the inhabitants of the Dungeon was an essential opposition to the mystical joy of the transformed Eros. So, something that is only implicitly indicated in the Ladder text itself, at least at first glance. 